\title{
KAJIAN KONSEP EKOLOGIS PADA GEDUNG PERPUSTAKAAN PUSAT UGM
}

\author{
Alifiano Rezka Adi \\ Program Studi Arsitektur, Fakultas Sains dan Teknologi, Universitas Teknologi Yogyakarta, \\ Jl. Glagahsari No. 63, Yogyakarta \\ Email: alifiano.rezka@staff.uty.ac.id
}

\begin{abstract}
Abstrak
Arsitektur ekologis menjadi salah satu konsep sekaligus solusi dalam perancangan suatu bangunan yang dapat meminimalisir kerusakan lingkungan serta menjaga kualitas hidup manusia di dalamnya. Bangunan perpustakaan pusat Universitas Gadjah Mada di Yogyakarta yang mengusung konsep green design digunakan sebagai objek penelitian untuk dianalisis tingkat ekologisasinya. Penelitian menggunakan metode kuantitatif dengan menilai tingkat ekologisasi bangunan berdasarkan prinsip-prinsip desain ekologis Sim Van der Ryn seperti "ecological accounting”, "design with nature", dan "making nature visible". Parameter penilaian didasarkan pada beberapa acuan seperti greenship yang dikeluarkan oleh GBCI, prinsip arsitektur tropis, dan prinsip aksesibilitas bangunan. Hasil penelitian menunjukkan bahwa secara umum bangunan telah mengaplikasikan konsep ekologis dengan baik melalui beberapa strategi desain diantaranya penghijauan yang cukup luas, efisiensi energi, pencahayaan alami yang memadahi, massa bangunan yang ramping, elemen shading sebagai peneduh, dan beberapa fasilitas untuk kaum difabel. Beberapa pengukuran dilakukan untuk mengetahui kinerja ekologis bangunan diantaranya efisiensi energi sebesar 39,17\%; daylighting 300 lux pada $60,67 \%$ area ruang dalam, visualisasi penerimaan radiasi matahari, dan nilai OTTV sebesar 19,85 watt $/ \mathrm{m}^{2}$. Meskipun begitu, terdapat beberapa evaluasi yang diperlukan seperti kebocoran pada plafon ataupun pengaplikasian greenroof yang dapat lebih dioptimalkan.
\end{abstract}

Kata kunci: desain ekologis, perpustakaan UGM Yogyakarta, greenship GBCI, arsitektur tropis, aksesibilitas

\begin{abstract}
Title: The Study of Ecological Concept in the Central Library of Gadjah Mada University

Ecological architecture becomes one of the concept as well as solutions in the building design which minimizes environmental damages and maintains the quality of human life. The central library of Gadjah Mada University in Yogyakarta is used as the research object to rate its ecological level. This study uses a quantitative method to rate its ecological level based on the ecological design principles of Sim Van der Ryn such as ecological accounting, design with nature, and making nature visible. The assessment parameters are based on some references such as the greenship of GBCI, the principles of tropical architecture, and the principle of building accessibility. The results showed that generally, the library has applied ecological concept well through some strategies such as extensive greening, energy efficiency, adequate natural lighting, slim building masses, shading elements, and some facilities for the difable. Some measurements are done to find out the ecological performance of the building such as energy efficiency by 39.17\%; daylighting 300 lux at 60.67\% of indoor area, visualization of solar radiation reception, and OTTV value by $19,85 \mathrm{watt} / \mathrm{m}^{2}$. However, there are some necessary evaluations such as leakage on the ceiling or the application of greenroof that can be further optimized.
\end{abstract}

Keywords: Ecological design, library of UGM Yogyakarta, greenship by GBCI, tropical architecture, accessibility 


\section{Pendahuluan}

Kondisi lingkungan yang ada saat ini sudah sangat mengkhawatirkan dengan berbagai anomali dan kerusakan seperti pemanasan global akibat dampak efek rumah kaca, perubahan iklim, krisis sumber daya alam, dan pencemaran limbah. Peningkatan tajam penggunaan energi yang terjadi saat ini tidak saja mengeksploitir sumber daya energi, tetapi juga dapat membahayakan lingkungan fisik alami dalam skala global (Loekita, 2006). Beberapa masalah inilah yang melatarbelakangi diadakannya KTT Bumi dan menghasilkan agenda 21 yang dicanangkan di Rio de Janeiro pada tahun 1992. Pertemuan ini sekaligus menunjukkan betapa pentingnya pembangunan berkelanjutan dalam segala aspek di jaman yang mengalami krisis lingkungan seperti saat sekarang ini (Aulia, 2005). Perubahan iklim global beserta isu-isu lingkungan mendorong keprihatinan masyarakat luas untuk berfokus mengedepankan pembangunan berkelanjutan (Chan \& Chow, 2014). Upaya mengintegrasikan pemahaman alam ke dalam perancangan ruang merupakan strategi kunci dalam menghadapi permasalahan pembangunan dan lingkungan saat ini (Verbeck \& Lakey, 1998). Bahkan kedepan, perancangan bangunan, baik residensial, komersial, ataupun institusional, harus bertujuan menciptakan 'zero energy building' yang mampu meminimalisir konsumsi energi dari jaringan listrik suatu daerah (Ali, 2008).

Arsitektur menjadi salah satu bidang ilmu yang dipandang memiliki andil bagi kerusakan lingkungan yang terjadi saat ini (Titisari, Triwinarto, \& Suryasari, 2012). Secara global, bangunan mengkonsumsi sekitar $40 \%$ dari total konsumsi energi tahunan dunia (Marique \& Reiter, 2014; Omer, 2008; Radhi, 2009). Oleh karena itu, munculah konsep sustainable architecture yang menjadi salah satu upaya untuk memperbaiki kerusakan lingkungan (Titisari, Triwinarto, \& Suryasari, 2012). Salah satu konsep yang berkembang dan menjadi rujukan dalam ilmu arsitketur adalah arsitektur ekologis. Konsep ini mengajarkan tentang hubungan timbal balik antara makhluk hidup dan lingkungannya (Frick, 1998). Pendekatan rancangan bangunan yang ekologis diharapkan dapat memberikan kontribusi positif terhadap perlindungan alam beserta sumber daya yang dikandungnya (Widigdo \& Canadarma, 2008).

Suatu bangunan dapat dikatakan ekologis atau tidak setelah melalui serangkaian penilaian ataupun analisa yang didasarkan atas prinsip-prinsip desain ekologis yang diterapkan pada bangunan tersebut (Ryn \& Cowan, 2006). Dalam paper ini, gedung Perpustakaan Universitas Gadjah Mada dipilih sebagai bangunan yang dianalisis tingkat ekologisasinya. Bangunan ini dirancang menggunakan konsep bangunan hijau atau green design.

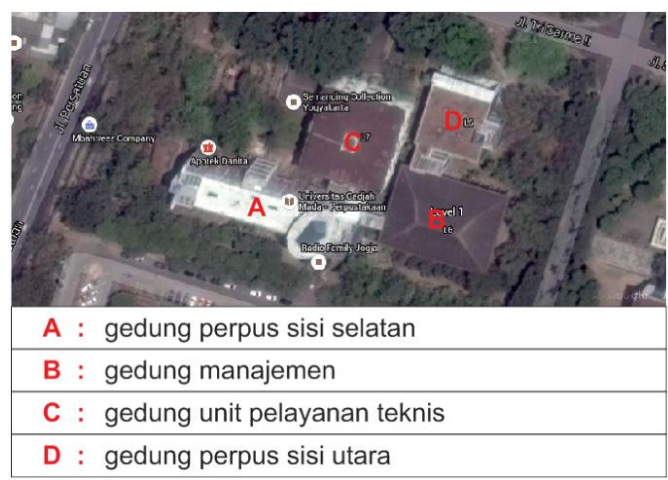

Gambar 1. Foto udara kompleks perpustakaan UGM

Sumber: Google Maps, 2016 


\section{Rumusan Masalah}

Rumusan penelitian dalam penelitian terhadap tingkat ekologisasi gedung perpustakaan UGM ini antara lain:

1. Bagaimana penerapan konsep desain ekologis pada Gedung Perpustakaan Universitas Gadjah Mada Yogyakarta?

2. Bagaimana evaluasi dan rekomendasi yang diperlukan dalam perancangan Gedung Perpustakaan Universitas Gadjah Mada Yogyakarta agar lebih ekologis?

Tujuan diadakannya penelitian ini adalah untuk mengetahui penerapan desain ekologis pada bangunan gedung Perpustakaan Universitas Gadjah Mada Yogyakarta. Selain untuk memahami lebih detail tentang teori arsitektur ekologis, penerapan desain ekologis pada bangunan perlu dianalisis untuk mengetahui pula kekurangan pada beberapa elemen bangunan yang perlu diperbaiki agar memiliki nilai ekologis lebih baik.

\section{Metode Penelitian}

Terdapat beberapa teori terkait dengan desain ekologis, baik dalam skala bangunan ataupun kawasan. Terdapat setidaknya lima prinsip dasar desain suatu bangunan yang ekologis menurut Sim Van der Ryn diantaranya adalah: solutions grow from place, ecological accounting, design with nature, everyone is a designer, dan making nature visible (Ryn \& Cowan, 2006). Prinsip-prinsip dari Sim Van der Ryn tersebut dalam beberapa tahun secara dinamis telah berkembang seiring dengan tantangan pembangunan yang berkembang sangat kompleks. Dalam penelitian ini, prinsip-prinsip arsitektur ekologis dari Sim Van der Ryn digunakan sebagai tolok ukur dalam menilai tingkat ekologisasi bangunan perpustakaan UGM. Meskipun begitu, tidak semua prinsip digunakan sebagai bahan analisis dikarenakan keterbatasan data yang didapatkan dilapangan. Analisa pada setiap prinsip dikolaborasikan dengan teori atau regulasi lain yang relevan dengan konsep pokok arsitektur ekologis.

Parameter penilaian pertama adalah terkait dengan prinsip ecological accounting. Prinsip ini menjadi kekuatan pokok dalam perancangan teknis suatu bangunan gedung (Ryn \& Cowan, 2006). Dalam penerapannya di Indonesia perangkat penilaian untuk bangunan hijau tercantum dalam greenship yang didukung oleh World Green Council, dan dilaksanakan oleh Komisi Rating dari Green Building Council Indonesia (GBCI, 2013) sebagai salah satu lembaga yang sangat peduli terhadap bangunan ramah lingkungan yang berbasis pada pembangunan berkelanjutan. Penggunaan greenship saat ini sangat diperlukan untuk mengukur tingkat keberlanjutan suatu bangunan dan untuk menjaga kualitas hidup manusia di dalamnya (Kusumawanto \& Astuti, 2014). Selain itu terdapat pula Peraturan Menteri PUPR tentang bangunan gedung hijau yang pada intinya memiliki tujuan yang sama dengan GBCI yaitu menjadi pengarah dan pengontrol pembangunan gedung ataupun kawasan yang berwawasan lingkungan. Adapun beberapa parameter dari greenship yang digunakan untuk menganalisis gedung perpustakaan ini antara lain:
a. Tepat guna lahan
b. Efisiensi energi
c. Kenyamanan termal ruang dalam 
Parameter berikutnya yaitu design with nature. Meskipun memiliki beberapa kesamaan dengan ecological accounting, elemen yang difokuskan adalah unsur fisik bangunan meliputi bentuk massa bangunan, orientasi, ataupun material bangunan. Design with nature dapat dikaitkan dengan teori bangunan tropis yang menjelaskan beberapa prinsip desain bangunan tropis. Teori ini dirasa relevan digunakan untuk menganalisis hubungan bangunan dengan alam karena memiliki konteks yang jelas yaitu bahwa bangunan berada di daerah beriklim tropis sehingga sebaiknya bangunan gedung Perpustakaan UGM juga menerapkan prinsip-prinsip bangunan tropis. Ossen dkk (2008) menjelaskan bahwa parameter desain arsitektur tropis didasarkan pada analisa beberapa elemen bangunan diantaranya:
a. Elemen atap
b. Elemen dinding
c. Elemen bukaan

Di dalam parameter making nature visible dijelaskan bahwa peningkatan pembangunan serta mobilisasi yang tinggi di kawasan perkotaan menjadikan bangunan beserta sistem yang ada didalamnya harus dapat terlihat dan diakses oleh semua kalangan, baik anak-anak ataupun orang dewasa (Ryn \& Cowan, 2006). Penjelasan tersebut menggambarkan bahwa bangunan ekologis khususnya yang berfungsi sebagai fasilitas publik seperti perpustakaan, seharusnya memiliki aksesibilitas yang baik untuk semua orang yang mendatanginya, termasuk kaum difabel (Kurniawan, 2014). Dalam konteks bangunan Indonesia, pengaturan tentang aksesibilitas pada bangunan telah diatur dalam peraturan menteri PU no 30/PRT/M/2006 tentang Pedoman
Teknis Fasilitas dan Aksesibilitas pada Bangunan dan Lingkungan. Parameter yang digunakan dalam analisa aksesibilitas dalam bangunan terdiri atas beberapa elemen bangunan (Kurniawan, 2014), diantaranya:
a. Sistem sirkulasi
b. Sistem informasi
c. Fasilitas penunjang

\section{Analisis dan Pembahasan}

Analisis tingkat ekologisasi pada gedung Perpustakaan UGM Yogyakarta dilakukan dengan mengambil bingkai tiga prinsip desain ekologis yang dikemukakan oleh Sim Van der Ryn yaitu ecological accounting, design with nature, dan making nature visible.

\section{Ecological Accounting}

Dalam konteks bangunan Indonesia, penilaian tingkat ekologi bangunan secara terukur telah tercantum dalam greenship yang dikeluarkan GBCI. Unsur-unsur dalam bangunan perpustakaan UGM ini dianalisis berdasarkan beberapa parameter yang tertuang dalam greenship.

Tepat Guna Lahan

Dalam tata aturan greenship dijelaskan bahwa tepat guna lahan mencakup kemampuan bangunan dalam memelihara atau memperluas kehijauan kota untuk meningkatkan kualitas iklim mikro. Perpustakaan UGM memang dikembangkan menjadi beberapa massa baru disekitar massa bangunan yang lama. Meskipun begitu perancangan bangunan baru tidak merusak bangunan yang lama dan tetap menyediakan ruang terbuka yang cukup luas di bagian halaman depan dan ruang-ruang diantara massa bangunan (Gambar 2). 


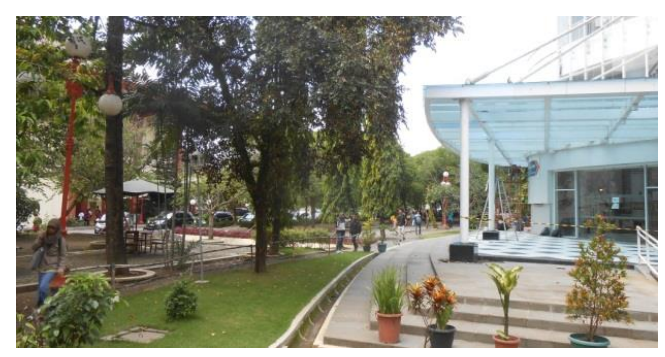

Gambar 2. Vegetasi di halaman depan

Sumber: Dokumentasi Penulis, 2016

Selain area hijau di halaman bangunan, terdapat pula area hijau di ruang atap atau greenroof yang terdapat di bangunan perpustakaan sisi Timur Laut. Adanya Greenroof ini sekaligus sebagai upaya untuk meminimalisir panas lingkungan/urban heat yang berasal dari pantulan radiasi panas perkerasan atap bangunan.

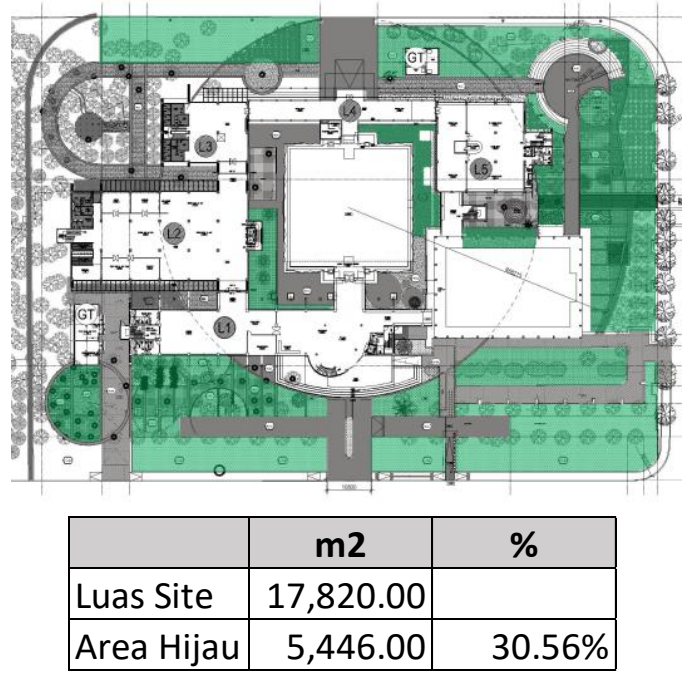

Gambar 3. Area lansekap berupa vegetasi dalam site

Sumber: Analisis Penulis, 2017

Jika dikalkulasi, total area hijau yang berada di kompleks perpustakaan kurang lebih seluas $5446 \mathrm{~m}^{2}$, atau sekitar 30,56\% dari luas site (Gambar 3). Greenship GBCI (2013) telah menetapkan standard area lansekap berupa vegetasi sebesar minimal 10\% dari luas total lahan, sehingga luas area lansekap pada perpustakaan UGM telah memenuhi persyaratan bangunan hijau.

\section{Efisiensi Energi}

Upaya efisiensi energi yang sedang gencar disuarakan dalam satu dekade terakhir mendorong perancangan perpustakaan UGM memperhatikan konsumsi energi yang digunakan. Upaya ini terlihat dari sistem pengudaraan pada sebagian besar ruang perpustakaan yang memanfaatkan sirkulasi udara alami melalui ventilasi ataupun bidang ruang yang terbuka.

Penghawaan buatan atau AC hanya digunakan pada ruang belajar dan ruang peminjaman buku. Alokasi penggunaan ruang ber-AC diminimalkan karena energi yang dibutuhkan oleh AC lebih besar dibandingkan energi lain untuk lampu penerangan ataupun lift (Gambar 4).

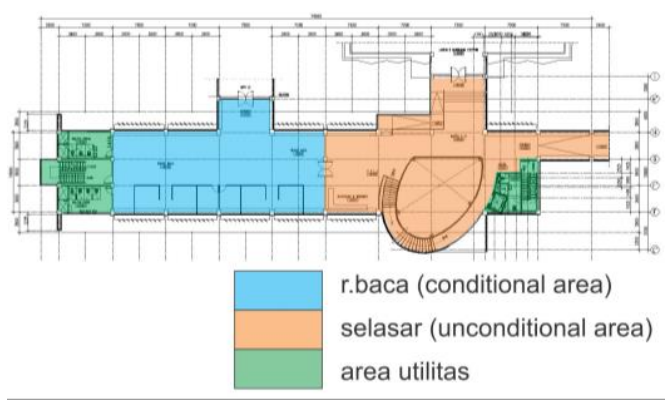

Gambar 4. Zoning penghawaan dalam ruangan

Sumber: Analisis Penulis, 2017

Untuk mengetahui efisiensi energi pada bangunan ini, maka dilakukan pengukuran menggunakan software EnergyPlus untuk mengetahui intensitas konsumsi energi (IKE) bangunan. Beberapa data teknis bangunan digunakan sebagai input data dalam simulasi diantaranya:

- Kaca: Panasap Euro Grey 8mm

- Dinding: bata ringan (hebel block)

- AC: tipe VRF dengan COP 4,2 
- Okupansi: 0,1 person $/ \mathrm{m}^{2}$ (asumsi)

- Lighting: 5 watt $/ \mathrm{m}^{2}$

- Equipment: $10 \mathrm{watt} / \mathrm{m}^{2}$ (asumsi)

- Operasional: 5 days (8a.m-6p.m)

Untuk mengetahui efisiensi yang terjadi, IKE desain dibandingkan dengan IKE baseline. Perbedaan utama data baseline adalah pada lampu, besar $\mathrm{COP}$ (coefficient of performance) AC, dan jenis kaca. Data lampu yang digunakan pada baseline menyesuaikan standard daya pencahayaan pada SNI 03-6197 tentang konservasi energi pada sistem pencahayaan. COP AC pada baseline ditetapkan sebesar 3,70 berdasarkan tipe mesin varriable refrigerant value (BSN-SNI 03-6390, 2010). Sedangkan kaca yang data termalnya dapat memenuhi standard OTTV $35 \mathrm{watt} / \mathrm{m}^{2}$ sesuai persyaratan greenship (GBCI, 2013).

Tabel 1. Rekap hasil simulasi IKE lantai tipikal bangunan Perpustakaan UGM

\begin{tabular}{|c|c|c|c|}
\hline \multicolumn{4}{|l|}{ BASELINE } \\
\hline & Electricity (kWh) & IKE (kWh/m2) & portion (\%) \\
\hline cooling & 15317.99 & 46.75 & $44.96 \%$ \\
\hline lighting & 13784.70 & 42.07 & $40.46 \%$ \\
\hline equipment & 3157.58 & 9.64 & $9.27 \%$ \\
\hline lift \& pump & 1807.37 & 5.52 & $5.31 \%$ \\
\hline Total & 34067.63 & 103.97 & \\
\hline \multicolumn{4}{|l|}{ DESAIN } \\
\hline & Electricity (kWh) & IKE (kWh/m2) & portion (\%) \\
\hline cooling & 9749.10 & 29.75 & $47.04 \%$ \\
\hline lighting & 6009.75 & 18.34 & $29.00 \%$ \\
\hline equipment & 3157.58 & 9.64 & $15.24 \%$ \\
\hline lift \& pump & 1807.37 & 5.52 & $8.72 \%$ \\
\hline Total & 20723.79 & 63.25 & \\
\hline \multicolumn{4}{|l|}{ SAVING } \\
\hline & Saving (kWh) & Saving $(\mathrm{kWh} / \mathrm{m} 2)$ & Saving (\%) \\
\hline cooling & 5568.89 & 17.00 & $36.36 \%$ \\
\hline lighting & 7774.95 & 23.73 & $56.40 \%$ \\
\hline equipment & 0.00 & 0.00 & $0.00 \%$ \\
\hline lift \& pump & 0.00 & 0.00 & $0.00 \%$ \\
\hline Total & 13343.84 & 40.72 & $39.17 \%$ \\
\hline
\end{tabular}

Sumber: Analisis Penulis, 2017

Hasil simulasi pada lantai tipikal gedung menunjukkan IKE desain adalah $63 \mathrm{kWh} / \mathrm{m}^{2} /$ th sedangkan IKE baseline sebesar $103,97 \mathrm{kWh} / \mathrm{m}^{2} / \mathrm{th}$, sehingga penghematan yang terjadi adalah sebesar $40,72 \mathrm{kWh} / \mathrm{m}^{2} /$ th atau sekitar 39,17\% (Tabel 1). Penghematan ini dapat tercapai diantaranya karena penggunaan kaca dengan kinerja termal yang baik, AC dengan nilai COP tinggi, lampu hemat energi, bukaan yang menghadap sisi UtaraSelatan, dan elemen shading pada fasad bangunan.

Kenyamanan termal ruang dalam

Kondisi kenyamanan termal dalam ruangan menjadi salah satu kriteria dalam greenship. Kenyamanan termal dalam ruangan di gedung Perpustakaan UGM dicapai dengan pencahayaan alami serta sirkulasi udara yang baik. Massa bangunan yang ramping pada sisi Utara-Selatan menjadikan akses pencahayaan alami dapat masuk secara optimal melalui kedua sisi ini sehingga ruang dalam mendapatkan penerangan alami yang merata. Gambar 5 menunjukkan bagaimana cahaya alami dari sisi Utara dan Selatan dapat masuk secara optimal melalui bukaan-bukaan yang ada sehingga ruang dalam mendapatkan intensitas cahaya yang cukup merata.

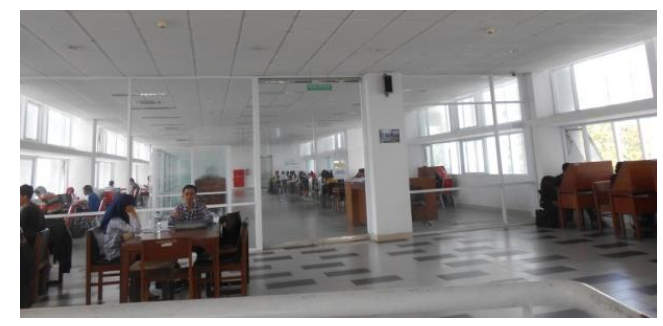

Gambar 5. Kondisi ruang dalam ketika siang hari

Sumber: Dokumentasi Penulis, 2016

Standard tingkat pencahayaan pada ruang perpustakaan adalah sebesar 300 lux (BSN-SNI 03-6197, 2010). Sedangkan menurut standard yang telah ditetapkan GBCI (2013), minimal $30 \%$ luas lantai yang digunakan untuk bekerja mendapatkan intensitas cahaya alami minimal sebesar 300 lux. Persebaran pencahayaan alami dalam ruang perpustakaan diuji menggunakan 
software Dialux versi 6. Hasil simulasi menunjukkan bahwa ruang dalam perpustakaan memiliki intensitas cahaya sebesar 300 lux atau lebih pada $60,67 \%$ area dalam ruangan (Gambar 6). Kondisi ini karena massa bangunan yang ramping dan area bukaan yang cukup luas pada sisi Utara dan Selatan bangunan.

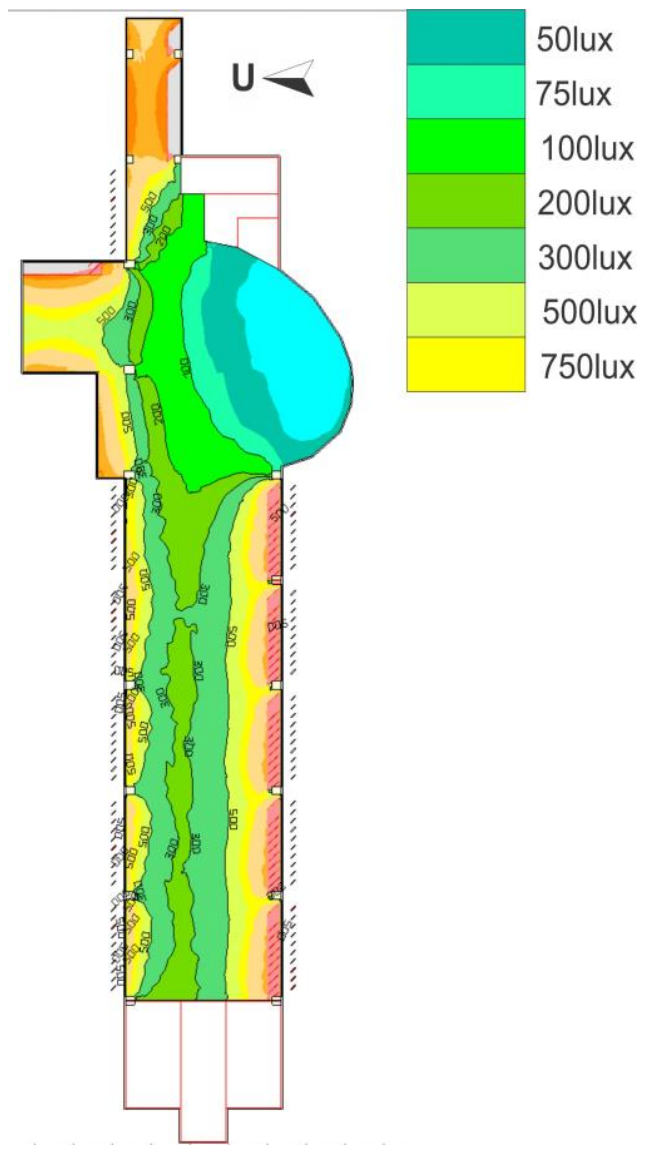

Gambar 6. Hasil simulasi daylighting menggunakan Dialux

Sumber: Analisis Penulis, 2017

\section{Design with Nature}

Pembahasan terkait dengan parameter design with nature disesuaikan dengan konsep desain bangunan tropis dengan memperhatikan beberapa elemen utama dalam bangunan seperti atap, dinding, dan bukaan (Ossen, Majid, \& Ahmad, 2008).
Massa Bangunan

Massa bangunan Perpustakaan UGM berbentuk ramping memanjang pada sisi Utara dan Selatan. Hal ini menyebabkan sisi Timur-Barat menerima radiasi matahari dalam jumlah yang tidak terlalu besar karena luasannya yang lebih kecil. Simulasi penerimaan radiasi matahari pada bangunan melalui software Ecotect dengan jelas menunjukkan perbedaan radiasi yang diterima pada sisi BaratTimur dibandingkan sisi Utara-Selatan. Sisi Utara mendapatkan radiasi sedikit lebih besar dibandingkan sisi Selatan karena pergerakan matahari yang lebih banyak pada sisi Utara (Gambar 7).

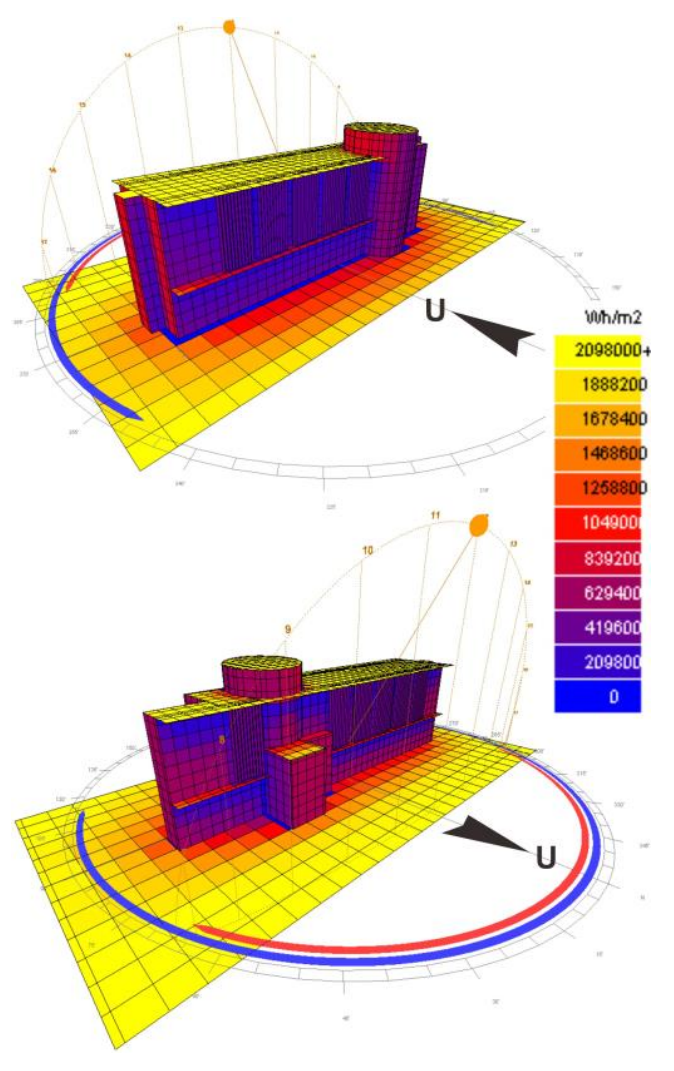

Gambar 7. Hasil simulasi penerimaan radiasi matahari dengan Ecotect Sumber: Analisis Penulis, 2017

Atap

Bangunan perpustakaan UGM merupakan bangunan yang memiliki desain relatif lebih modern dibandingkan beberapa bangunan 
disekitarnya. Untuk menunjang penampilan, atap bangunan menggunakan jenis atap datar dengan material beton (Gambar 8).

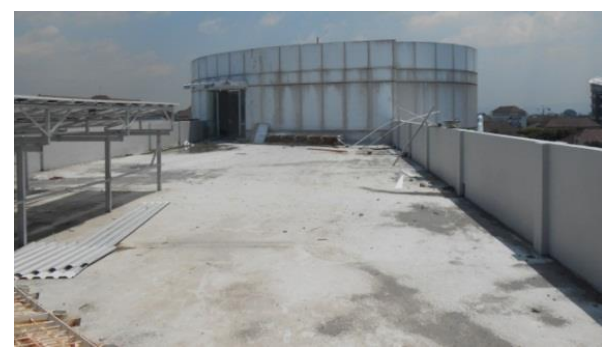

Gambar 8. Atap dak pada sisi Selatan Sumber: Dokumentasi Penulis, 2016

Pemilihan penggunaan atap datar untuk menunjang penampilan dan memudahkan sistem ME memiliki resiko karena berhadapan dengan panas lingkungan yang diakibatkan panas radiasi yang dipantulkan dari atap datar ini. Oleh karena itu greenroof menjadi opsi yang tepat untuk mengatasi masalah ini meskipun penerapan pada gedung Perpustakaan UGM masih sebatas gedung bagian Timur Laut saja.

Tantangan lain dari penggunaan atap datar adalah sistem drainase dalam menghadapi curah hujan tinggi di daerah beriklim tropis. Sistem drainase yang buruk akan beresiko menimbulkan genangan air pada atap datar dan juga kebocoran pada ruang dibawahnya. Kejadian ini terjadi di beberapa titik didalam Perpustakaan UGM. Beberapa bagian plafon terlihat mengalami kebocoran sehingga terdapat beberapa lubang pada plafon (Gambar 9).

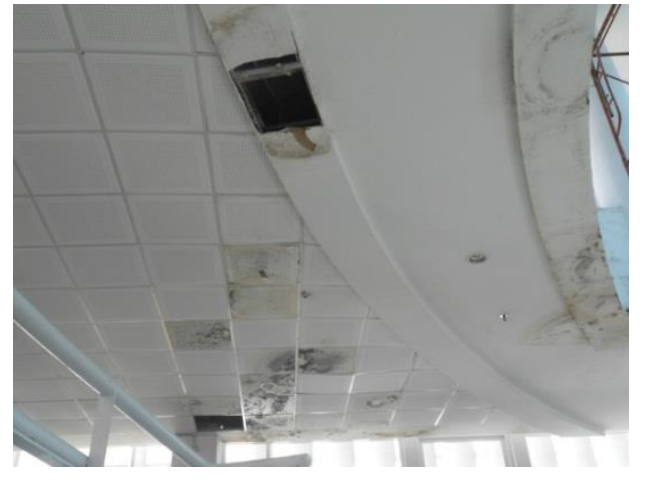

Gambar 9. Kebocoran pada plafon

Sumber: Dokumentasi Penulis, 2016

Dinding

Di daerah beriklim tropis, dibutuhkan sistem dinding yang memiliki insulasi termal yang baik sehingga dapat menjaga kenyamanan termal dalam bangunan dari panas eksternal (Ossen, Majid, \& Ahmad, 2008). Selain itu, desain selubung bangunan yang tepat akan mempengaruhi efisiensi energi dalam bangunan tersebut (Granadeiro, 2012). Dalam hal ini, Perpustakaan UGM menggunakan material dinding berbeda pada masing-masing sisi yang disesuaikan dengan orientasi dan fungsi ruang didalamnya.

Dinding pada sisi Timur dan Barat menggunakan dinding dengan material batu alam yang berwarna gelap (Gambar 10). Dinding pada sisi ini menerima radiasi matahari dalam jumlah paling besar sehingga penggunaan dinding berwarna gelap akan mengurangi dampak reflektivitas radiasi matahari ke lingkungan sekitar. Panas yang menyerap ke dalam ruangan diantisipasi dengan fungsi pendukung (toilet) sehingga tidak mengganggu kenyamanan kegiatan di dalam perpustakaan. 


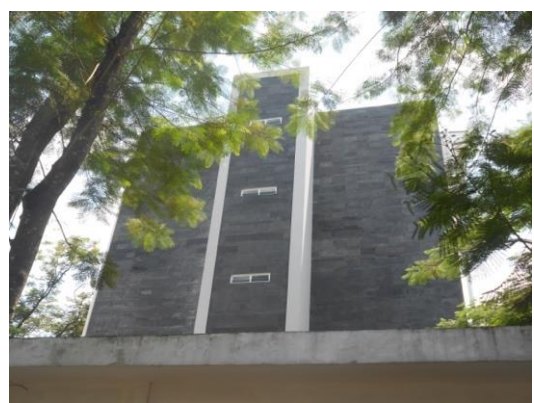

Gambar 10. Dinding sisi Barat

Sumber: Dokumentasi Penulis, 2016

Sedangkan dinding pada sisi UtaraSelatan menggunakan warna kombinasi hitam dan putih terang (Gambar 11). Warna terang pada lantai atas akan lebih meminimalisir penyerapan panas sehingga fungsi ruang didalamnya tetap terjaga kenyamanannya. Untuk mengantisipasi reflektivitas yang tinggi kelingkungan sekitar, fasad pada lantai bawah menggunakan dinding gelap dengan bukaan-bukaan berdimensi besar sehingga mengurangi luas permukaan dinding. Dengan begitu fungsi kegiatan utama perpustakaan akan mendapatkan akses pencahayaan alami secara optimal, suhu ruang tetap terjaga karena panas radiasi tidak begitu terserap dinding, dan reflektivitas radiasi ke lingkungan sekitar dapat diminimalisir dengan kombinasi bukaan dan dinding yang proporsional.

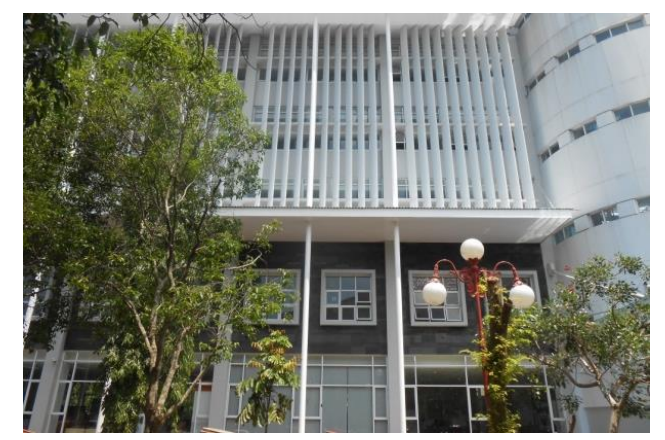

Gambar 11. Dinding sisi Selatan

Sumber: Dokumentasi Penulis, 2016
Bukaan

Bukaan pada bangunan perpustakaan UGM dirancang terutama pada sisi Utara dan Selatan fasad bangunan. Hal ini dilakukan untuk meminimalisir masuknya radiasi matahari dari arah Timur dan Barat bangunan.

Selain sistem bukaan yang ada, dinding pada lantai atas dilengkapi dengan shading vertikal yang bertujuan untuk mengontrol cahaya yang masuk kedalam ruangan. Shading vertikal ini juga memiliki sedikit kemiringan ke arah Timur Laut, menyesuaikan orientasi bangunan yang sedikit miring ke arah Tenggara. Dengan begitu posisi shading dapat saling tegak lurus dengan arah datang sinar matahari sehingga sistem pembayangan dapat berjalan optimal. Adapun dinding pada lantai bawah tidak menggunakan shading vertikal karena telah terlindungi oleh overhang dari lantai di atasnya (Gambar 12). Peran dari desain bukaan dan sistem shading yang diterapkan dapat terlihat dari kecilnya nilai OTTV bangunan Perpustakaan UGM ini (Tabel 2).

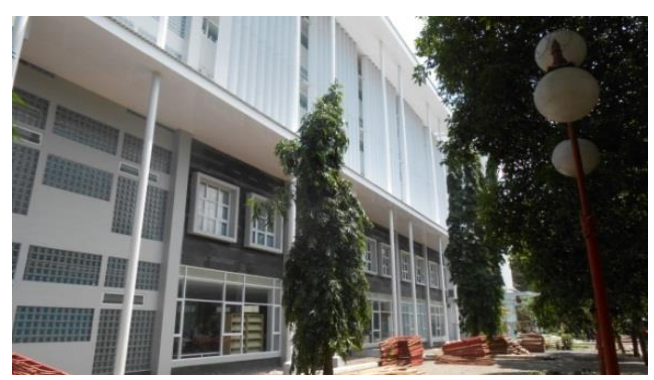

Gambar 12. Sistem bukaan pada fasad sisi Selatan

Sumber: Dokumentasi Penulis, 2016

Selain sistem shading exterior, terdapat pula shading horizontal dalam bangunan. Shading ini selain berperan untuk memecah cahaya yang masuk juga berfungsi untuk memantulkan cahaya yang masuk ke dalam ruangan sehingga distribusi cahaya dari luar 
dapat masuk lebih dalam dan merata karena efek pemantulan yang terjadi. Manfaat lain dari adanya shading ini adalah orang di dalam ruangan tidak mendapatkan efek glare yang berlebihan karena cahaya dari luar tidak langsung masuk namun dipantulkan terlebih dahulu (Gambar 13).

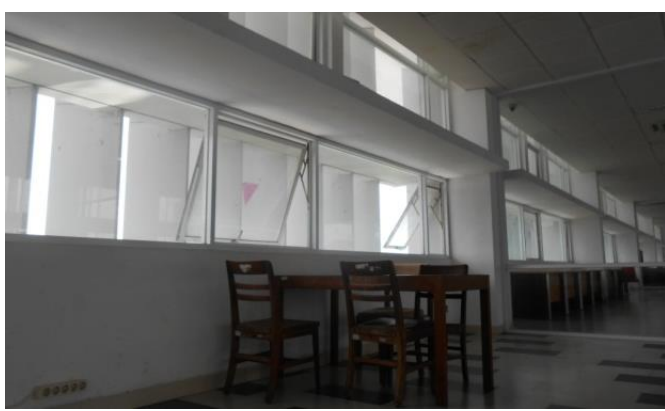

Gambar 13. Shading horizontal interior Sumber: Dokumentasi Penulis, 2016

Peran sistem bukaan dan shading dalam kinerja termal bangunan kemudian diuji menggunakan software EnergyPlus untuk mengetahui perolehan OTTV (Overall Thermal Transfer Value) bangunan Perpustakaan UGM. Sebagaimana yang telah diketahui, OTTV merupakan parameter yang umum digunakan untuk menguji kinerja termal suatu bangunan. GBCI (2013) telah menetapkan standard OTTV di Indonesia adalah sebesar $35 \mathrm{watt} / \mathrm{m}^{2}$ (BSN-SNI 6389, 2011). Hasil simulasi menunjukkan bangunan Perpustakaan UGM memiliki nilai OTTV sebesar $19,85 \mathrm{watt} / \mathrm{m}^{2}$ (Tabel 2). Sebagaimana hasil simulasi sebelumnya dengan Ecotect, sisi Utara mendapatkan radiasi lebih besar dibandingkan sisi Selatan sehingga perolehan OTTV pada sisi Utara juga lebih besar. Tidak terdapat nilai OTTV pada sisi Timur dan Barat karena tidak ada sisi ruang ber-AC pada sisi-sisi ini.
Tabel 2. Rekap perhitungan OTTV lantai tipikal bangunan Perpustakaan UGM

\begin{tabular}{|l|r|c|r|c|r|}
\hline & \multicolumn{1}{|c|}{ North } & East & \multicolumn{1}{c|}{ South } & West & \multicolumn{1}{c|}{ Total } \\
\hline WINDOW HEAT GAIN (W) & $\mathbf{2 , 6 3 0 . 2 2}$ & - & $1,782.12$ & - & $4,412.34$ \\
\hline WALL CONDUCTION (W) & 227.09 & - & 174.44 & - & 401.53 \\
\hline EXTERNAL HEAT GAIN (W) & $2,857.31$ & - & $1,956.56$ & - & $4,813.87$ \\
\hline GLASS AREA (m2) & 55.60 & - & 55.60 & - & 111.20 \\
\hline TOTAL AREA (m2) & 121.26 & - & 121.26 & - & 242.52 \\
\hline OTTV (W/m2) & 23.56 & & 16.14 & & 19.85 \\
\hline WWR (\%) & $45.9 \%$ & & $45.9 \%$ & & $45.9 \%$ \\
\hline
\end{tabular}

Sumber: Analisis Penulis, 2017

\section{Making Nature Visible}

Telah dijelaskan sebelumnya bahwa pembangunan modern telah mendorong mobilisasi yang tinggi di kawasan perkotaan. Bangunan yang bersifat publik harus dilengkapi dengan penyediaan fasilitas dan aksesibilitas bagi semua orang termasuk penyandang cacat dan lansia (Peraturan Menteri PU, 2006). Hal ini dalam teori desain ekologis Sim Van der Ryn termasuk ke dalam kategori making nature visible. Analisis dalam gedung Perpustakaan UGM ini dilakukan pada beberapa elemen dalam bangunan dan dibandingkan dengan standard aksesibilitas di dalam Peraturan Menteri PU tentang Pedoman Teknis Fasilitas dan Aksesibilitas pada Bangunan Gedung dan Lingkungan. Elemen dalam bangunan yang dianalisis dibagi kedalam tiga kategori yaitu sistem sirkulasi, sistem informasi, dan fasilitas penunjang.

Sistem Sirkulasi

Sistem sirkulasi dalam Perpustakaan UGM terdiri dari beberapa elemen mulai dari ramp, tangga, dan lift. Terdapat beberapa ramp yang ada dalam Perpustakaan UGM. Ramp yang pertama terdapat dekat dengan pintu masuk bangunan atau entrance (Gambar 14). Ramp ini menghubungkan bagian halaman depan dengan pintu masuk perpustakaan. Ramp dibuat dengan kemiringan yang cukup landai dan menggunakan material lantai conblock 
dan plesteran semen kasar sehingga lantai tidak licin. Selain itu ramp juga dilengkapi handrail untuk membantu pengguna kruk atau orang tua saat melalui ramp.

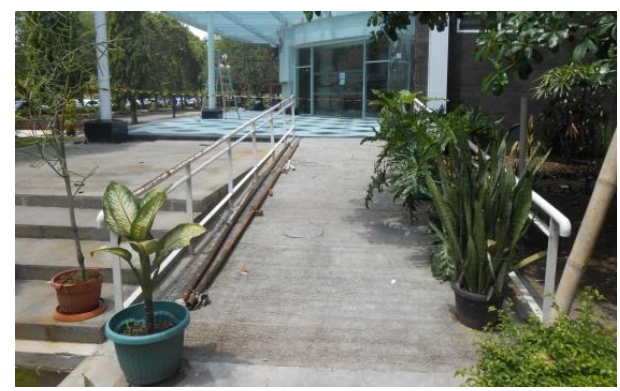

Gambar 14. Ramp entrance

Sumber: Dokumentasi Penulis, 2016

Ramp lain terdapat pada koridor yang menghubungkan antar massa bangunan (Gambar 15). Meskipun terdapat perbedaan level antar massa bangunan, penyelesaian desain tidak menggunakan perbedaan level lantai atau trap, melainkan dengan ramp yang memiliki kemiringan sangat landai sehingga memudahkan pengguna kursi roda untuk mengakses jalur ini secara mandiri.

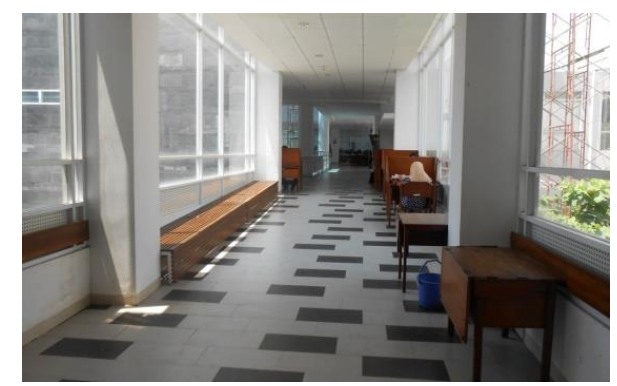

Gambar 15. Ramp diantara 2 bangunan Sumber: Dokumentasi Penulis, 2016

Tangga dalam Perpustakaan UGM menjadi elemen utama mobilisasi vertikal bagi pengunjung ataupun pengelola perpustakaan (Kurniawan, 2014). Tangga dibuat dengan dimensi uptrade, untrade, handrail, lebar anak tangga, serta jumlah anak tangga sesuai standard yang memungkinkan anak- anak, orangtua, ataupun pengguna kruk mengakses tangga secara mandiri.

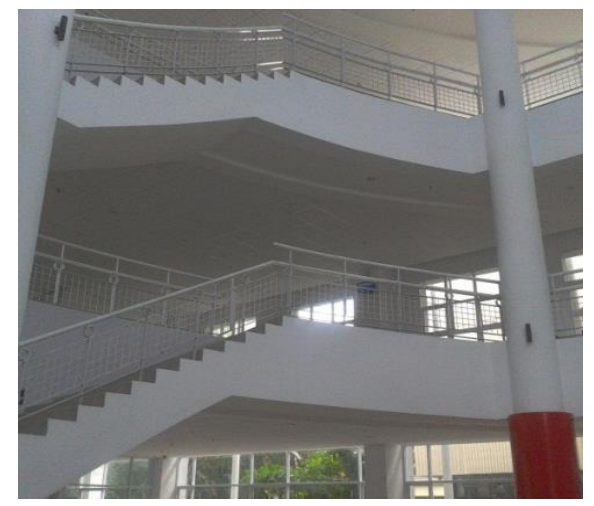

Gambar 16. Tangga utama pada bangunan Sumber: Dokumentasi Penulis, 2016

Pada tahun 2012, beberapa mahasiswa arsitektur UGM beserta UNS melakukan simulasi aksesibilitas pada Perpustakaan UGM ini. Berperan seakan-akan menjadi kaum difabel, hasil simulasi menunjukkan bahwa para mahasiswa relatif tidak mengalami kesulitan dalam menggunakan beberapa jalur sirkulasi dalam perpustakaan ini.

Dimensi ruang lift pada Perpustakaan UGM memungkinkan pengguna kursi roda ataupun masuk dan keluar ruang lift secara mandiri karena beberapa fasilitas yang mendukung seperti handrail di dalam ruang lift, tombol kontrol lift disertai huruf braile yang terjangkau, dan cermin dalam ruang lift (Gambar 17).
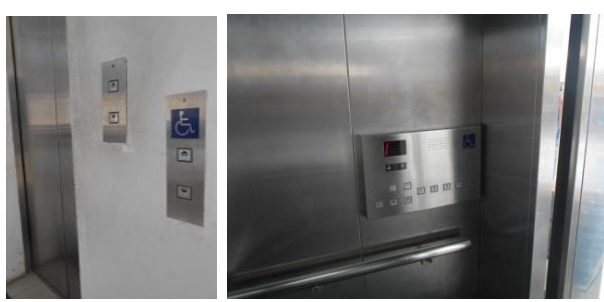

Gambar 17. Lift beserta fasilitasnya untuk kaum difabel

Sumber: Dokumentasi Penulis, 2016

Sistem Informasi 
Sistem informasi dalam bangunan dirancang dengan memperhatikan kaum difabel agar mendapatkan informasi yang dibutuhkan dengan mudah dan lancar. Akses informasi yang pertama adalah meja informasi yang terletak di bagian lobby utama bangunan (Gambar 18).

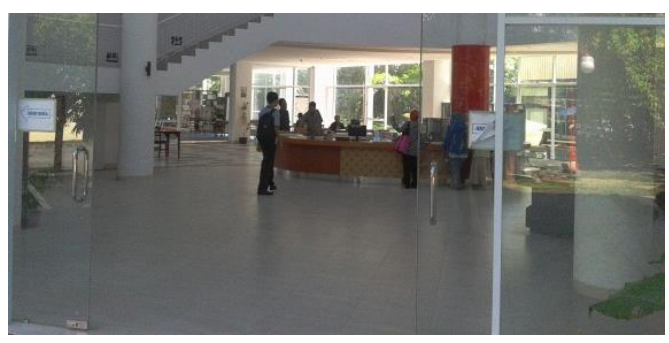

Gambar 18. Spot informasi di lobby utama Sumber: Dokumentasi Penulis, 2016

Akses langsung dari pintu geser otomatis lobby masuk memudahkan kaum difabel mendapatkan informasi awal dari perpustakaan ini dengan cepat dan mudah. Selain itu untuk memudahkan pencarian lokasi dalam perpustakaan disediakan peta timbul atau tactile map sehingga memudahkan kaum tunanetra dalam mencari informasi lokasi dalam perpustakaan (Gambar 19). Peta timbul ini terdapat disetiap lantai bangunan dekat dengan lift sebagai satu kesatuan akses mobilitas dan peta yang informatif.

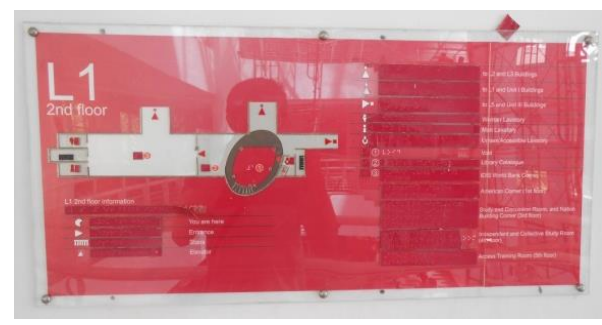

Gambar 19. Peta timbul disetiap lantai Sumber: Dokumentasi Penulis, 2016

Fasilitas Penunjang (Toilet Difabel)

Toilet sebagai fasilitas penunjang dalam bangunan dirancang agar memiliki aksesibilitas yang baik terutama untuk kaum difabel. Dimensi ruang dalam toilet cukup luas untuk pengguna kursi roda. Pintu geser dan handrail yang lengkap dalam ruang toilet memudahkan kaum difabel dalam melakukan buang air dengan aman secara mandiri (Gambar 20).
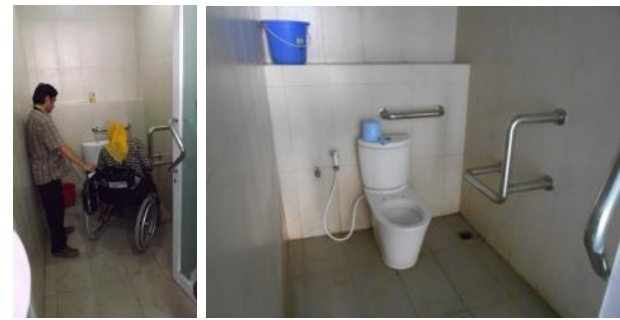

Gambar 20. Ruang toilet yang aksesibel Sumber: Dokumentasi Penulis, 2016

\section{Kesimpulan dan Rekomendasi}

\section{Kesimpulan}

Prinsip desain ekologis Sim Van der Ryn yang digunakan sebagai parameter dalam penelitian ini adalah ecological accounting, design with nature, dan making nature visible. Secara umum, gedung Perpustakaan UGM telah mengaplikasikan konsep ekologi dengan baik melalui beberapa strategi. Meskipun begitu terdapat beberapa kekurangan yang berakibat kerusakan pada elemen tertentu.

Dalam parameter Ecological accounting, bangunan telah diupayakan mencapai green design melalui beberapa strategi seperti pengoptimalan ruang terbuka hijau, penggunaan greenroof, minimalisir alokasi penggunaan $\mathrm{AC}$, penggunaan material alam, serta pengoptimalan pencahayaan dan sirkulasi udara alami. Beberapa pengukuran dilakukan pada strategi desain yang diterapkan diantaranya efisiensi energi sebesar $39,17 \%$ dan daylighting 300 lux pada $60,67 \%$ area ruang dalam.

Dalam parameter design with nature, terdapat beberapa evaluasi terhadap 
beberapa elemen bangunan. Dalam hal ini atap bangunan yang datar diduga menjadi salah satu penyebab kebocoran pada beberapa titik dalam bangunan. Akibatnya banyak plafon yang mengalami kerusakan dan harus direnovasi. Meskipun begitu, bentuk massa bangunan yang ramping memanjang pada sisi Utara-Selatan dapat mengurangi penerimaan panas radiasi matahari oleh bangunan. Sedangkan elemen dinding dan bukaan telah dirancang cukup baik dengan menerapkan prinsip desain bangunan tropis yang merespon panas lingkungan, pencahayaan, dan pengudaraan alami. Peran dari bentuk massa, orientasi, bukaan, dan sistem shading pada bangunan terlihat dari pengukuran OTTV bangunan yang tergolong baik yaitu sebesar kurang lebih $19,85 \mathrm{watt} / \mathrm{m}^{2}$.

Sedangkan dalam parameter making nature visible, aksesibilitas gedung perpustakaan menjadi fokus perhatian dalam penelitian ini. Dalam hal ini, Perpustakaan UGM telah menerapkan desain yang aksesibel untuk kaum difabel melalui beberapa elemen seperti pada sistem sirkulasi, sistem informasi, serta fasilitas penunjang.

\section{Rekomendasi}

Terdapat setidaknya dua hal yang menjadi evaluasi sekaligus dapat dikoreksi untuk desain Perpustakaan UGM yang lebih ekologis kedepannya. Dua hal tersebut adalah penghijauan dan material atap bangunan.

Penghijauan pada bangunan perlu lebih dimaksimalkan terutama pada bagian atap bangunan. Greenroof yang ada sekarang perlu diperluas ke bagian atap bangunan perpustakaan bagian Selatan. Atap dengan perkerasan beton yang ada sekarang menimbulkan panas lingkungan/urban heat (Gambar 21).
Pengadaan greenroof yang optimal disertai sistem konstruksi yang memadai diharapkan dapat menambah responsibilitas bangunan terhadap isu panas lingkungan.

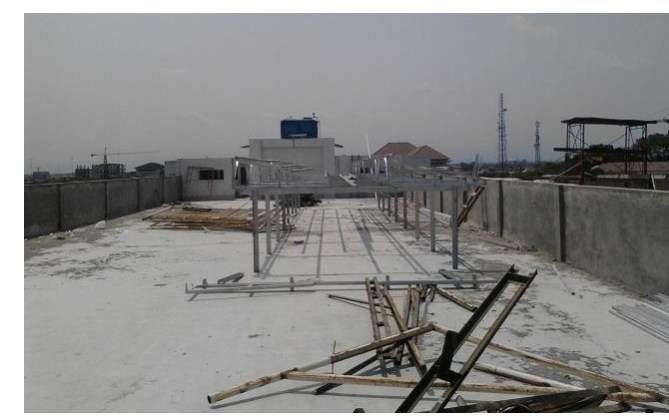

Gambar 21. Atap perpustakaan bagian Selatan yang dapat dikembangkan menjadi greenroof

Sumber: Dokumentasi Penulis, 2016

Evaluasi kedua adalah pada material atap bangunan. Kerusakan pada beberapa plafon lantai atas bangunan diduga sebagai akibat adanya kebocoran atap bangunan yang kebetulan berupa atap datar (Gambar 22). Atap datar dengan dalam kasus ini lebih beresiko mengalami kebocoran dibandingkan jika bangunan menggunakan atap miring. Meskipun begitu bangunan tidak dapat begitu saja mengganti atap dengan atap miring karena pertimbangan keselarasan desain bangunan.

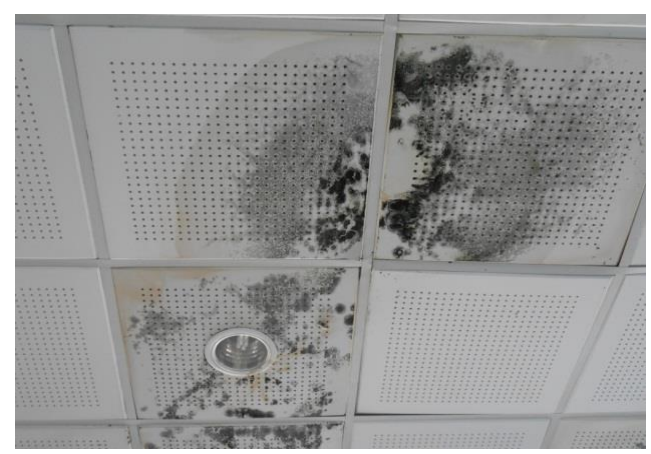

Gambar 22. Plafon yang bocor sehingga memerlukan renovasi

Sumber: Dokumentasi Penulis, 2016 
Beberapa strategi yang dapat dilakukan untuk mengatasi kebocoran atap ini antara lain:

a. Menggunakan material plafon gypsum atau material lain yang memiliki kemampuan water resistant. Meskipun dengan harga yang lebih mahal, plafon jenis ini akan lebih awet karena dapat tahan terhadap kontak dengan air. Material juga dapat diberi lapisan tambahan berupa cat minyak untuk lebih meminimalisir resiko bocor.

b. Melapis atap dak beton dengan terlebih dahulu dilakukan tes waterproofing untuk mengukur nilai surut air. Upaya ini untuk memastikan atap dak tidak mengalami kebocoran dikemudian hari.

\section{Daftar Pustaka}

Ali, M. M. (2008). Energy efficient architecture and building systems to address global warming. Leadership and Management in Engineering.

Aulia, D. N. (2005). Permukiman yang berwawasan lingkungan. Jurnal Sistem Teknik Industri Volume 6, No. 4, 1-5.

Badan Standarddisasi Nasional. (2010). SNI 03-6197 tentang konservasi energi pada sistem pencahayaan.

Badan Standarddisasi Nasional. (2010). SNI 03-6390 tentang konservasi energi sistem tata udara bangunan gedung.

Badan Standarddisasi Nasional. (2011). SNI 6389-2011 tentang konservasi energi selubung bangunan pada bangunan gedung.

Chan, A., \& Chow, T. (2014). Calculation of overall thermal transfer value for commercial buildings constructed with naturally ventilated double skin Facade in subtropical Hong Kong. Energy and Buildings, 69, 14-21.

Frick, H. (1998). Dasar-dasar arsitektur ekologis. Yogyakarta: Kanisius.

Granadeiro, V. d. (2012). Building envelope shape design in early stages of the design process. Automation in Construction, 2, 196-209.

Green Building Council Indonesia. (2013). Greenship untuk bangunan baru v1.2.

Kurniawan, H. (2014). Implementasi aksesibilitas pada gedung baru perpustakaan UGM. Indonesian Journal of Disability Studies Vol.1 Issue 1, 44-51.

Kusumawanto, A., \& Astuti, Z. B. (2014). Arsitektur hijau dalam inovasi kota. Yogyakarta: Gadjah Mada University Press.

Loekita, S. (2006). Analisis konservasi energi melalui selubung bangunan. Dimensi Teknik Sipil, 8, 93-98.

Marique, A., \& Reiter, S. (2014). A simplified framework to assess the feasibility of zero-energy at the neighbourhood/community scale. Energy and Buildings, 82, 114-122.

Menteri Pekerjaan Umum. (2006). Peraturan menteri PU no 30/PRT/M/2006 tentang pedoman teknis fasilitas dan aksesibilitas pada bangunan dan lingkungan.

Omer, A. (2008). Energy, environment and sustainable development. Renewable and Sustainable Energy Reviews, 12, 2265-2300.

Ossen, D. R., Majid, R. B., \& Ahmad, M. H. (2008). Tropical building design principles for comfortable 
indoor environment. Malaysia:

Faculty of Built Environment

Universiti Teknologi Malaysia.

Radhi, H. (2009). Evaluating the potential impact of global warming on the UEA residential buildings. Building and Environment, 44, 2451-2462.

Ryn, S. V., \& Cowan, S. (2006). Ecological design redux. Buildings for the 21 st Century, 14.

Titisari, E. Y., Triwinarto, J., \& Suryasari, N. (2012). Konsep ekologis pada arsitektur di Desa Bendosari. Jurnal RUAS, Volume 10 NO 2, 1693-3702.

Verbeck, B. J., \& Lakey, J. S. (1998). Ecological aesthetics, humane design. ASCE Engineering Approaches to Ecosystem Restoration, 1-6.

Widigdo C. W., \& Canadarma, I. K. (2008). Pendekatan ekologi pada rancangan arsitektur sebagai upaya mengurangi pemanasan global. Prosiding Seminar Nasional Lingkungan Hidup. 